PaWEe KAŹMIERSKI iD http:/orcid.org/0000-0001-8287-3419 Jagiellonian University in Kraków

Maciej MikuŁa iD http:/orcid.org/0000-0001-6708-004X Jagiellonian University in Kraków

\title{
Report from the Webinar "Difficult Heritage: the Interwar Codification Movement in Central and Eastern Europe (1918-1939)" - 7 October 2021
}

On October 7, 2021, an English-language workshop was held in the form of a webinar, organized as part of the research project entitled "Continuity and Discontinuity of Prewar Legal Systems in Post-war Successor States (1918-1939)". The project was financed by the International Visegrad Fund (project website: http://www.wyznaniowe.law.uj.edu. pl/visegrad, accessed: 30.09.2021) ${ }^{1}$. The webinar was co-organized by Dr. Hab. Maciej Mikuła, Professor of the Department of the Ecclesiastical Law and Law on Religious Denominations at the Faculty of Law and Administration at the Jagiellonian University in Kraków in cooperation with Prof. Tomáš Gábriš (University of Trnava), Dr. Vilém Knoll (University of West Bohemia in Plzeň) and Dr. Hab. Norbert Varga (University of Szeged). During the webinar, a comparative analysis of codification movements in the interwar period in three countries of the contemporary Visegrad Group (Czechoslovakia, Poland, and Hungary) was undertaken. The project participants were researchers from four academic centres representing the University of Szeged (Hungary), the Jagiellonian University in Kraków (Poland), the University of Trnava (Slovakia), and the University of West Bohemia in Plzeň (Czechia). The webinar also crowned one of the tasks of the project, consisting in the translation into English of selected legal acts adopted in the years 1918-1939 in Czechoslovakia, Poland, and Hungary (available on the "IURA. Sources

1

- Visegrad Fund - $\bullet$
The project 'Continuity and Discontinuity of Pre-war Legal Systems in Post-war Successor States (1918-1939)' is co-financed by the Governments of Czechia, Hungary, Poland and Slovakia through Visegrad Grants from International Visegrad Fund. The mission of the fund is to advance ideas for sustainable regional cooperation in Central Europe. Visegrad Grant No. 22030159. 
of old law" project website: https://iura.uj.edu.pl/dlibra/publication/2214\#structure, accessed: 30.09 .2021 ).

In a short introduction, Prof. Mikuła pointed out that the webinar was organized as part of a project financed by the International Visegrad Fund, in which the Jagiellonian University acts as a leader, along with its partners, the universities of Plzeň, Szeged, and Trnava. Prof. Bartosz Brożek, Deputy Dean of the Faculty of Law and Administration of the Jagiellonian University conducted the ceremonial opening of the meeting. In his speech, he pointed out two important reasons why legal-historical research is necessary in contemporary jurisprudence. The first is the history of law, that is, the history of identifying problems and solving them. The second being that the past is a reservoir of cases. These two circumstances make the experience of the past important in thinking about the law of the future. Subsequently, the honor of chairing the morning session was handed over to Dr. Hab. Varga.

In the first session entitled "Continuity and Discontinuity" two speakers from the University of Plzeň spoke. Dr. Tomas Pezl presented the first paper entitled "Continuity and discontinuity in the inter-war law on the example of Czechoslovak criminal law", which was co-authored by Dr. Vilém Knoll. Dr. Petr Dostalik subsequently presented a speech entitled "Unwanted continuation. The institution of so-called versio in rem in the Austrian Civil Code and inter-war legal discussion in Czechoslovakia". After a short discussion, there was a break before continuing the morning part of the meeting.

The second morning session entitled "Successful Legislation" was moderated by Dr. Vilém Knoll. The papers were delivered by two researchers from the University of Szeged; Dr. Hab. Norbert Varga presented "Introduction of the cartel regulation in Hungary in the interwar period: and Dr. Máté Pétervári presented "Changes of the insolvency law in Hungary in the interwar period". After a short discussion, there was a longer break before the next webinar session.

The third session entitled "Projects" was chaired by Prof. Maciej Mikuła. The papers were delivered by: Dr. Hab. Zdzisław Zarzycki (Jagiellonian University in Kraków) entitled "Attempts to codify the personal marriage law in the Second Polish Republic: A fiasco or perhaps a success?" and Dr. Stanislav Balik (University of Plzeň) "Projects of unification of laws about advocacy and notariate in the First Czechoslovak Republic (1918-1938)". After the discussion, the participants went on a lunch break.

The fourth session entitled "Judiciary" was chaired by Prof. Tomáš Gábriš of the University of Trnava. Presentations were given by: Dr. Kristóf Szivós (University of Szeged) entitled "The changes in the right of novelty in Hungarian civil procedure in the interwar period", Dr. Jakob Maziarz (Jagiellonian University in Kraków) "Jury courts in inter-war Poland" and Michal Tomin MA (University of Trnava) "Successful unification of the institution of adoption in the interwar Czechoslovakia" The co-author of the paper was Prof. Miriam Laclavíková.

The fifth session entitled "Comparative Studies" was chaired by Dr. Hab. Jan Halberda of the Jagiellonian University in Kraków. Three papers were delivered as part of the legal and comparative session by: Dr. Ingrid Lanczová (University of Trnava) entitled "Mental disorder as a ground for divorce in the Czechoslovak marriage amendment and comparison to Hungarian law", Prof. Tomáš Gábriš (University of Trnava) "Slovak viewpoint on unification and codification efforts in Czechoslovakia" and 
Krzysztof Bokwa MA (Jagiellonian University in Kraków) "Civil liability ex delicto: Austrian law - Hungarian law - Polish interwar law". After a discussion with the speakers, the moderator of the session invited Prof. Mikuła to give a short summary of the webinar. He thanked all the speakers individually for their speeches, which showed that the problems that the legislators of interwar Czechoslovakia, Poland and Hungary had to deal with were quite similar. All of the speakers were invited to submit manuscripts of their articles for publication in the journal Cracow Studies of Constitutional and Legal History. Thanks were also addressed to the discussants and moderators of the session, and the essential role that the International Visegrad Fund played in financing the project was emphasized.

It should further be emphasized that the event not only enabled the exchange of mutual experiences among researchers from various university centers representing four countries of Central and Eastern Europe, but may also successfully contribute in the future to further strengthening international cooperation, especially in the context of conducting historical and legal research in the comparative approach of the Visegrad Group countries. 
